\title{
TAREKAT KHALWATIAH SAMMAN DAN AJARANNYA
}

\author{
Samsul Marlin \\ Universitas Pamulang \\ dosen00640@unpam.ac.id
}

Naskah diterima: 25 November 2019, direvisi: 30 November 2019, disetujui: 18 Desember 2019

\section{Abstrak}

Khalwatiah Samman masuk ke Sulawesi Selatan di bawah oleh Abdullah Munir pada tahun $1240 \mathrm{H}(1825 \mathrm{M})$. la bangsawan bugis dari Bone (cucu Raja Bone La Temmasonge, berkuasa 1775-1812). Tarekat itu diterima di Sumbawa (NTB) kemudian dikembangka oleh anaknya sendiri, Muhammad Fudail (w 1859). Pada mulanya Tarekat ini diterima oleh keluarga bangsawan dan sebagian mereka kelak menjadi Raja di Sulawesi Selatan, seperti Raja Bone, Ahmad bin Idris (1860-1871), Raja Gowa, Mallingkaan Daeng Nyonri (1893-1895), Arung Matoa Wajo, Andi Manggawarani (1900-1919), selain Raja, ada juga bangsawan lainnya, seperti Watang Lipu (panglima perang), Petta Ambona Lamassalangka di Kerajaan Soppeng dan Petta Bella Arung Toa Abd. Razak (w 1902), keluarga Muhammad Fudail, dan muridnya dari Barru ke Maros sebagai pusat penyebaran Tarekatnya.

Penelitian ini menggunakan metode kualitatif lapangan dan pustaka, dengan mengurut sejarah Khalwatiah Samman, metode diskusi juga dilakuakn oleh peneliti, ditemukan beberapa hasil dari penelitian ini sebagaimana yang dituangkan di dalam artikel ini.

Kata kunci: Tarekat Khalwatiyah Samman. 


\section{Pendahuluan}

Kata tarekat berasal dari bahasa Arab, yang artinya jalan, sirat dan mazhab.' Kata thariq juga dipakai dalam Al Qur'an yang mengacu kepada jalan yang ditempuh seseorang untuk mengerjakan sesuatu. ${ }^{2}$

Dalam bahasa Indonesia, kata tarekat mempunyai beberapa pengertian, yaitu jalan, cara, aturan dan persekutuan para penuntut tasawuf, ${ }^{3}$

Martin Van Bruinessen memberikan ulasan tentang kata tarekat dengan arti "jalan" mengacu baik kepada sistim latihan meditasi maupun amalan (muraqabah, dzikir, wirid, dan sebagainya), yag dihubungkan dengan sederet guru sufi, dan organisasi yang tumbuh di seputar metode sufi khas ini. Praktek ibadah Tarekat

Khalwatiah Samman yang diajarkan khalifah kepada jamaahnya memiliki tata cara tersendiri seperti:

I. Bai'at, merupakan pintu masuk bagi anggota jamaah yang ingin masuk dalam Tarekat Khalwatiah Samman

'Ibrahim Anis, dkk Al Mu'jam Al Wasit Juz Il (Mesir, Dar al Ma'arif 1393 H/1973 M) h 556

${ }^{2} \mathrm{Di}$ dalam Al Qur'an kata thariq disebut sebanyak tujuh kali, empat kali dalam kata mufrad, tiga kali dalam bentuk kata muannas, Muhammad Fuad al Baqiy, Al Mu'jam Mufradat Al Faz Al Qur'an (Bairut Dar Al Fikr), h 312

Indonesia (Jakarta Balai Pustaka Cet 111 1990) h 903 adalah merupakan sumpah setiah kepada pemimpin. Oleh karena itu seseorang yang akan menjadi anggota Tarekat Khalwatiyah Samman terlebih dahulu melalui upacara, yang dikenal dengan istilah mattarima barakka (Bugis), annarima barakka (Makassar) yang arti harfiahnya menerima berkah. Firman Allah dalam Al Qur'an surat Al Fath (48):10

Artinya: "bahwasanya orang-orang yang berjanji setia kepada kamu Sesungguhnya mereka berjanji setia kepada Allah. tangan Allah di atas tangan mereka, Maka Barangsiapa yang melanggar janjinya niscaya akibat ia melanggar janji itu akan menimpa dirinya sendiri dan Barangsiapa menepati janjinya kepada Allah Maka Allah akan memberinya pahala yang besar".

Dzikir, yang diartikan dengan menyebut, dalam Tarekat Khalwatiyah Samman, dzikir adalah lafal-lafal yang diajarkan oleh Khalifah dan diucapkan secara teratur untuk mendekatkan diri kepada Allah swt, sehingga dzikir biasa juga disebut dengan ratib. Sebutan ratib dikalangan Tarekat Khalwatiyah Samman Sulawesi Selatan dikenal dengan paddate (orang, ratib). Firman Allah dalam Al Qur'an surat Al Ra'd (13):28 
“(yaitu) orang-orang yang beriman dan hati mereka manjadi tenteram dengan mengingat Allah. Ingatlah, hanya dengan mengingati Allah-lah hati menjadi tenteram."

Sholat Jum'at, bagi pengikut Khalwatiah Samman, disamping melaksanakan sholat Jum'at, dilakukan juga sholat zhuhur setelah selesai melaksanakan sholat jum'at. Hal ini bagi mereka bukan hal yang perlu diperdebatkan. Dalam pemahaman Tarekat Khalwatiah Samman alif lam yang terdapat pada kata sholat pada ayat 9 surat al jumu'ah adalah al ma'rifah yang sudah jelas peruntukannya yakni khusus bagi sholat jum'at. Qurat Surat Al Jumu'ah $(62): 9$

"Hai orang-orang beriman, apabila diseru untuk menunaikan shalat Jum'at, Maka bersegeralah kamu kepada mengingat Allah dan tinggalkanlah jual beli, yang demikian itu lebih baik bagimu jika kamu mengetahui."

Sementara kata sholat pada ayat 10, memakai alif lam jinsiah yang oleh Tarekat Khalwatiah Samman, selain sholat jum'at ada sholat lain yang harus dilakukan setelah jum'at yaitu sholat zhuhur.

"apabila telah ditunaikan shalat, Maka bertebaranlah kamu di muka bumi; dan carilah karunia Allah dan ingatlah Allah banyak-banyak supaya kamu beruntung."

\section{Metode}

Penelitian ini tergolong penelitian dengan pendekatan kualitatif dengan metode desktiptif analisis. Metode kualitatif merupakan suatu penelitian yang berorientasi pada fenomena atau gejala yang bersifat alami. Peneliti mengumpulkan data dan pengambilan dokumen pada situasi yang wajar dan alamiah, apa adanya.

Sumber data penelitian diambil dari bahan-bahan primer maupun sekunder, dalam hal ini yang menjadi bahan primer adalah buku Study Pendidikan Islam, Eksiklopedia Islam, Al-Quran dan Hadis, artikel pendidikan Islam, Majalah, serta literature literatur lain sehingga layak dipandang sebagai documentary research. Dan bahan sekunder literatur yang mendukung penelitian ini. Penulis juga telah mengunjungi beberapa masjid Khalwatiah Samman di beberapa daerah. Informasi ini diperoleh juga dari Khalifah Khalwatiah Samman Drs. H. Andi Hidayat (Puang Daya) seorang Khalifah Khalwatiah Samman wilayah Turikale - Maros.

\section{HASIL DAN PEMBAHASAN}

\section{Ajaran Tarekat Khalwatiah Samman}

\section{Syariah dan Hakikat}

Syari'ah dalam pengertian umum tidak terbatas pada fikih atau hukum, 
tetapi mencakup pula akidah dan akhlak. Syariah mengandung arti tauhid kepada Allah, kitab-kitab, kepada rasulrasul-Nya, dan hari pembalasan, yang kemudian mengantarkan orang untuk dikatakan muslim. ${ }^{4}$

Sedangkan Abbas Husni Mahmud menegaskan bahawa syariah identik dengan kandungan Al-Qur'an dan Sunnah, sehingga syariah secara keselurihan disebut al-Din. ${ }^{5}$ Menurut Ahmad Sirhindi, dalam kitabnya Maktubat, syariah itu bukan sekedar kumpulan undang-undang atau peraturan yang mengatur tindakan yang lahir. Akan tetapi syariah juga menjelaskan tentang keimanan, tauhid, cinta, syukur, sabar, ibadah, zikir, jihad, takwa, dan ihsan. Syariah berkaitan lahir dan batin seperti pikiran dan kehendak, iman, niat, perasaan, dan emosi. Syariah dan hakikat adalah kesatuan yang tak terpisahkan. $^{6} \quad$ Pada perkembangan kemudian syari'ah adalah hukum Islam.

Para sufi dan pengamal tarekat sering dituduh mengabaikan syariah,

\footnotetext{
${ }^{4}$ Sa'ad Ibn Sa'ad 'Ali Duraib, dalam Hamka Haq, Syariah Islam: Wacana dan Penerapannya, Ujung Pandang: Yayasan alAhkam, 2001, h 16

${ }^{5}$ Sa'ad Ibn Sa'ad 'Ali Duraib, dalam Hamka Haq, Syariah Islam: Wacana dan Penerapannya, Ujung Pandang: Yayasan alAhkam, 2001, h 16-17

${ }^{6}$ Muhammad Abd Haq Anshari, Sufisme dan Syari'ah: "A Study of Shaikh Sirhindi's to Reform Sufism", alih bahasa Ahmad Nasir Budiman Antara Sufisme dan Syariah, Cet Il, Jakarta: PT Raja Grafindo Persada 1993, h 110
}

sufi hanya berinteraksi kepada hakikat. Tuduhan semacam ini berlangsung sampai sekarang hingga datangnya alGhazali. Oleh karena itu al-Ghazali dianggap sufi yang dapat mendamaikan. ${ }^{7}$ Akan tetapi tuduhan seperti itu tidak berhenti, seperti tuduhan kepada Tarekat Khalwatiah Samman di Sulawesi Selatan. Abdullah al-Marusi menulis buku yang diberi judul Hujjah al-Maftuhin (dalil orang yag difitnah). Dalam naskah Hujjah alMaftuhin, Abdullah al-Marusi menjelaskan bahwa jalan menuju Allah sangat banyak, sebanyak tarikan nafas mahluk. Semua tarekat hanya dinisbahkan kepada dua shahabat Nabi saw, yaitu Abu bakar Ashshiddiq dan Ali bin Abi Thalib. Satu-satunya tarekat yang berasal dari Abu Bakar Ashshiddiq adalah Tarekat Naqsyabandiyah bahwa Allah swt, tidak membatasi hamba untuk menuju kepada-Nya. Oleh karena itu seseorang boleh saja mengamalkan lebih dari satu tarekat. Dalam safinah al-Najah, Syaikh Yusuf menyebutkan 16 tarekat yang diterima, mulai dari Aceh, Yaman, Mekah, Madinah, Iraq, Damaskus, Bait al-Maqdis sampai ke Hindustan. Menurut Syaikh Yusuf

${ }^{7}$ Muhammad Abd Haq Anshari, Sufisme dan Syari'ah: "A Study of Shaikh Sirhindi's to Reform Sufism", alih bahasa Ahmad Nasir Budiman Antara Sufisme dan Syariah, Cet II, Jakarta: PT Raja Grafindo Persada 1993, h 11 
semua tarekat yang diterimanya itu silsilahnya bersambung sampai kepada Nabi saw, tetapi hanya lima yang disebut lengkap dalam buku tersebut, yaitu Tarekat Qadiriyah diterima dari Muhammad Jilani al-Raniri, paman Nuruddin ar-Raniri di Aceh, Tarekat Naqsabandiyah di terima dari Syaikh Abdullah bin Abd al-Baqi al-Syaikh alKabir al-Mazjaji al-Yamani alNaqsabandi di Yaman, Tarekat Ba'lawiyah diterima dari Sayyid 'Ali di Yaman, Tarekat Syattariyah diteriman dari Ibrahim Hasan bin Syihab al-Din alKurdi di Madinah, dan Tarekat Khalwatiyah diterima dari Abi al-Barakat Ayyub al-Khalwati di Damaskus. Dalam naskah Safinah al-Najah, Syaikh Yusuf menjelaska perlunya mencari Syaikh (guru tarekat). Persyaratan yang harus dimiliki oleh seorang Syaikh tarekat antara lain ia memahami dan melaksanakan syariah, sedangkan kewajiban seorang murid antara lain baiat. ${ }^{8}$ Dalam sebuah karya Syaikh Yusuf yang ditulis oleh Maisur disebutkan bahwa diantara guru Tarekat Qadiriyah Syaikh Yusuf adalah Siraj al-Din di Banda Aceh. ${ }^{9}$

${ }^{8}$ Syaikh Yusuf al-Maqasari, Safinah al-Najah

${ }^{9}$ Maysur bin Jami al-Din al-Maqasariy, Lontara Syaikh Yusuf Lontara ini milik almarhum Haji Hasbdullah, anak kadi Gowa.
Dalam mukaddimah buku Malqutah min Riyad at-Tasawwuf karya khalifah Tarekat Khalwatiah Samman, Abdullah al-Marusi menulis pada permulaan buku tersebut pada pujian kepada Allah swt, bahwa Allah yang menjadikan syariah dan hakikat saling terkait, dan salah satunya tidak bermanfaat tanpa yang lainnya. Sebagaimana sabda Nabi Muhammad saw., syariah tanpa hakikat kosong, dan hakikat tanpa syariah batil, syariah bagaikan kulit sedangkan hakikat adalah isinya. Kulit tanpa isi tidak akan tumbuh, sedangkan isi tanpa kulit adalah kerusakan.

Ungkapan di atas memberikan petunjuk bahwa syariah itu amat penting, tidak dapat ditinggalkan. Seseorang dalam perjalanannya mencari Tuhan, kemudian merasa menemukan hakikat, ia samasekali tidak boleh meninggalkan syariah, karena keduanya yaitu syariah dan hakikat tidak dapat dipisahkan. Al-Marusi mengutip ungkapan Abu Bakar al-Daqqaq "apabila telah ditunaikan shalat, Maka bertebaranlah kamu di muka bumi; dan carilah karunia Allah dan ingatlah Allah banyak-banyak supaya kamu beruntung."

Fotokopi naskah diperoleh pada bulan Ahmad Rahman bulan Nopember 2010. 


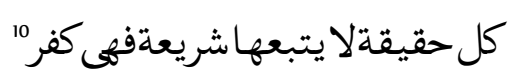

"Setiap hakikat yang tidak disertai dengan syariah adalah kekafiran"

Selanjutnya al-Marusi menjelaskan bahwa hakikat dan syariah keduanya tidak boleh diabaikan. Syariah adalah lahir sedangkan hakikat adalah batin, keduanya mempunyai ibadah tersendiri. Untuk jelasnya dikutip ungkapan alMarusi sebagai berikut:

"Issengngi sio majeppu Allataala pancaji pakkasiyang sareya enrenge napacanji pakkasiyang bateng enrenge napancajitokkeng sininna tauwe tubu laherang enrenge tabu bateng enrenge padapunnai pakkasiyang yaduwa. Naiyya pakkasiyanna tubu leheratta iyanaritu deceng ripogaue enrenge ribacabacae. latona nabicara kitta ussulu enrenge iyatona nawawa tubu. lyatona riyaseng ahlussunnati walejamaati. Naiyya pakkasiyang atie iyanaritu perenngerannge ri Allataala ia nawawa ati ayatona bicaranna kitta tasaupu".

Dengan terjemahan:

Ketahuilah bahwa Allah menjadikan ibadah syariah dan ibadah batin. la juga menjadikan tubuh lahir dan tubuh batin bagi manusia, keduanya mempunyai cara pelaksanaan ibadah. Ibadah tubuh lahir yaitu perbuatan baik dan ucapan yang baik. Itulah yang dibicarakan fikih dan kitab usul dan itu yag dibawah

\footnotetext{
${ }^{10}$ Abdullah al- Marusi, Malqutah min Riyadd at-Tasawwuf, h 1
}

tubuh. Itulah yang disebut ahlussunnah waljamaah. Sedangkan ibadah hati adalah ingatan kepada Allah yang dibawa hati dan itu adalah dibicarakan dalam kitab tasawuf.

Ungkapan di atas dapat dipahami bahwa Allah telah menetapkan adanya lahir yaitu syariah dan batin yaitu hakikat, dan mempunyai ibadah tersendiri, ibadah lahir baik perbuatan, maupun perkataan masuk wilayah pembicaraan fikih dan usul fikih, sedangkan ibadah batin adalah ibadah hati, yaitu selalu mengingat Allah (zikir), kapan dan dimana saja, baik dalam keadaan berdiri, duduk dan berbaring. Sehingga diperoleh batin atau hati hendaknya selalu kontak kepada Allah, selalu mengingat jepadaNya.

Beberapa sufi dalam bukunya memuat syariah sebagai pembahasan awal sebelum memasuki pembahasan hakikat yang merupakan kajian tasawuf. Seperti Hamzah Fansuri, sufi nusantara abad ke 16 dalam bukunya Syarb alAsyikin (minuma para pecinta) yang membagi tujuh bab, dan bab pertama dinamai 'amal dan al-syariah (amal syariah). Sesudah amal as-syariyyah menyusul 'amal al-tariqah (amalan tarekat), amal al-haqiqah, ma'rifah Allah, tajalli zat Allah (nyata zat Allah), sifat Allah, al-isyq wa al-syukr (cinta dan syukur). Menurut Hamzah Fansuri, syariah adalah sabda Nabi saw, 
menyuruh kita berbuat baik, melarang kita berbuat jahat. Adapun perkara, pertama syahadat, kedua sembahyang fardu, ketiga memberi zakat, keempat puasa, dan kelima naik haji bagi yag mampu." Pengertian hamzah Fansuri tidak juga membatasi hanya masalah fikih, tetapi mencakup juga tauhid. Begitu pula Khalifah Tarekat Khalwatiah Samman Abdullah al-Bone, dimana salah satu karyanya adalah fikih ${ }^{12}$

Menurut al-Marusi hubungan syariah dengan hakekat seperti kulit dengan isi yang tidak dapat dipisahkan. Sedangkan Hamzah Fansuri membuat

"Hamzah Fansuri, Syarb al-Asyikin, dalam Syed Muhammad Naquib al-Attas, The Mysticisme of Hamzah Fansuri Kuala Lumpur, University of Malaya Press 1970, h 301-303

${ }^{12}$ Abdullah al-Bone, Kumpulan tulisan yang terdiri atas: 1. Burdah, memuat sejarah nabi dalam bentuk syair, karya seorang penulis Mesir, al-Busiri (1213-1297), naskah tidak lengkap, tidak ada halaman awal, mulai halaman 1-79. diterjemahkan dalam bahasa Bugis oleh Abdullah al-Bone. 2. Tauhid, tidak diketahui judul naskah, bahasa Arab, anskah sebagian besar tidak dapat dibaca, isinya antara lain aqidah tentang hari kiamat, pertemuan Allah dengan hambanya di akhirat, halaman akhir naskah terdapat doa-doa, diantaranya doa dan hadiah al-fatihah kepada Syaikh-Syaikh Tarekat Khalwatiyah, halaman 79-90. 3. Fikih tidak ada judul, halaman awal tidak ada, permulaan naskah berbicara tentang tahara, macam-macam najis, salat, puasa, hadis-hadis, seperti hadis tentang syurga. Pada ahir naskah tertulis. Tamat hazhi al-hadits laila al-sabt bi'auni Allah malik al-wahhab (tanpa tahun), disebut nama penulis Abdur Razak bin Abdullah, mulai halaman 91185. 4. Risalah al-gausiyah, dialog Syaikh Abdul Qadir Jaelani (1078-1168 M). Dengan Allah, mulai halaman 186-194. 5. Al-Nafahat al-Illahiyat, karya Abdul Karim Al-Samman (w 1775), mulai halaman 195-375 perumpamaan dengan hakekat, bagaikan kulit dengan otak, jika tidak ada kulit binasa otak. Lebih lanjut Hamzah Fansuri membuat perumpamaan hubungan syariah, tarekat, hakikat, dengan ma'rifat, yaitu bagaikan kelapa, kulitnya adalah syariah, tempurungnya adalah tarekat, isinya adalah hakikat, sedangkan minyaknya adalah ma'rifat. Dengan empat hal itu makan sempurnalah hukumnya. Kalau salah satu dari empat hal itu hilang, tidak sempurna lagi. Kalau kelapa ditanam tanpa kulit, tidak akan tumbuh dan akhirnya binasa. Demikian pula bagi orang yang menuntut (mencari) Allah swt, selama ia tidak memisahkan keempat hal itu yaitu syariah, tarekat, hakikat, ma'rifat, maka ia akan memndapatkan kesempurnaan. Akan tetapi jika syariah ditinggal maka ia dalalah (sesat) hukumnya. Sekalipun ia dapat terbang di udara, berjalan di atas air, makan api itu adalah kedustaan dan jalannya sesat. la bukan seorang wali karena hal itu tidak termasuk kekeramatan, tetapi ia berasal dari syethan, jin atau sihir. Seorang ulama yang mendapat kekeramatan, karena ia menjalankan syariah sehingga ia dapat disebut wali, sedangkan bagi nabi disebut mu'jizat. Bagi ahl ma'rifat, kekeramatan itu adalah hijab dan quyud (jamak dari qayd yang artinya pengikat), 
karena kekeramatan itu bahanya banyak, tidak banyak orang yag mendapat kekeramatan dapat selamat. Orang yang memakai syariah, tarekat, hakikat dan ma'rifat amalannya seperti amalan nabi Muhammad saw, orang seperti itu bagaikan mentri yang setia mengerjakan perintah raja. Sekalipun ia jauh dari raja tetapi pangkatnya lebih tinggi dari orang yang tinggal didalan pagar (istana), karena mentri adalah khalifah raja, dan pemegang kekuasaan raja. Jangan dikira syariah itu kecil, karena Allah itu bernama zahir dan batin. Zahir itu adalah syariah dan batin itu adalah hakekat. Bagi orang awam, memang ada perbedaan antara syariah dengan hakikat, sedangkan bagi ahl ma'rifat syariah dan hakekat sama saja. Syariah berlindung kepada hakekat sedangkat hakekat berkandung kepada syariah. ${ }^{13}$

Dalam Hujjah al-Maftunin, karya Abdullah al-Marusi dikemukakan pentingnya mempelajari tasawuf. la mengutip ungkapan al-Ghazali ( $w$ IIII M)
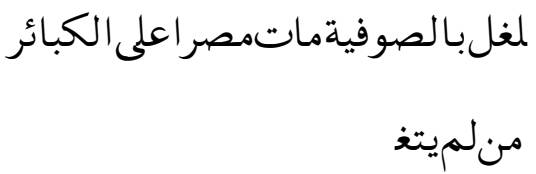

${ }^{13}$ Hamzah Fansuri, Syarb al-Asyikin, dalam Syed Muhammad Naquib al-Attas, The Mysticisme of Hamzah Fansuri Kuala Lumpur, University of Malaya Press 1970, h 295-296
Barang siapa tidak menaruh perhatian kepada tasawuf, maka ia mati tetap pada dosa besar.

Begitu pentingnya mempelajari tasawuf, Abdullah al-Marusi juga mengutip pendapat al-junaid al-bagdadi (w $910 \mathrm{M}$ ), seandainya manusia mengetahui keutamaan ilmu Allah ini lebih afdal daripada seluruh ilmu, maka ia berusaha untuk mencarinya sekalipun diujung dunia. Al-Marusi juga mengajak Muslimin bergegas mencari ilmu ini, namun ia mengakui bahwa ilmu tersebut sangat sulit dan orang yang mendapatkannya disebut karena inayat Allah, selanjutnya al-Marusi menjelaskan bahwa sebenarnya jalan kepada Allah sangatlah sulit, maka kewajiban abdi Allah bersungguh-sungguh menuju jalan Allah, dan sesungguhnya Allah akan memberinya hidayah. Al-Marusi mengutip Al-Qur'an Surat al-Ankabut (29):69

"dan orang-orang yang berjihad untuk (mencari keridhaan) Kami, benar- benar akan Kami tunjukkan kepada mereka jalan-jalan kami. dan Sesungguhnya Allah benar-benar beserta orang-orang yang berbuat baik." QS. Al-Ankabut (29): 69

Bagi orang yang mempunyai kehendak kepada Allah (murid) ia selalu ada harapan (raja') pertemuan dengan Allah (liqa Allah). Seseorang yang ingin liqa Allah, harus didahului dengan harapan liqa Allah. Hal ini dapat dilihat 
dalam Al-Qur'an surat al-Ankabut (29) ayat 5 yang berbunyi sebagai berikut:

"Barangsiapa yang mengharap Pertemuan dengan Allah, Maka Sesungguhnya waktu (yang dijanjikan) Allah itu, pasti datang. dan Dialah yang Maha mendengar lagi Maha mengetahui." QS. Al-Ankabut (29):5

Namun untuk dapat bertemu dengan Allah (liqa'Allah) tidak cukup hanya harapan (raja'), tetapi harus disertai dengan usaha yang sungguhsungguh. Hal ini sesuai dengan firman Allah dalam Al-Qur'an surat al-Insyiqaq (84) ayat 6 yang berbunyi sebagai berikut:

"Hai manusia, Sesungguhnya kamu telah bekerja dengan sungguh-sungguh menuju Tuhanmu, Maka pasti kamu akan menemui-Nya." QS. Al-Insyiqaq (84):6

Dalam dunia tarekat yang dimaksud dengan sungguh-sungguh pada surat al-insyiqaq di atas adalah zikir secara berjamaah riyadah (latihan) seperti yang dilakukan Tarekat naqsabandiyah yang dinamai suluk ${ }^{14}$

\section{Baiat}

Kata bai'at berasal dari bahasa arab yang berarti ikatan. ${ }^{15}$ Kata ini telah

${ }^{14}$ Ahmad Rahman, Tarekat Sammaniyah Penyebaran dan Ajaran di Sulawesi Selatan (Disertasi UIN Jakarta th 2008), h 175

${ }^{15}$ lbrahim Anis dkk, Al Mu'jam Al Washil Juz 1 (Mesir Dar Al Maarif 1392 H/1972 M), h 79 sudah menjadi perbendaharaan bahasa Indonesia yang dapat berarti pengangkatan, pelantikan secara resmi, pengucapan sumpah setia kepada pemimpin. ${ }^{16}$ Baiat adalah perjanjian dalam ketaatan. Seakan-akan mereka yang berjanji kepada pemimpinnya untuk menyerahkan urusannya dan urusan orang muslim. Mereka taat dan tidak menentang pemimpin dimana ia mengangkat baiat. Kala berbaiat, mereka meletakkan tangannya kepada pemimpin dimana ia berbaiat, seperti pembeli dan penjual. Oleh karena itu dinamai baiah (jual beli), kemudian kata ini dapat berarti musafahah bi al-aidi (berjabat tangan). ${ }^{17}$

Secara historis, baiat bermula ketika Nabi saw, mengutus Usman bin Affan ke Mekah, kemudian tersebar berita bahwa ia dibunuh oleh orang musyrik. Menurut Hisyam dalam bukunya Sirah ibn Hisyam bahwa lshaq berkata: Abdullah bin Abu Bakar memberitahukan bahwa Rasulullah saw, bersabda: Ketika sampai kepadanya berita tentang kematian Usman bin Affan, ia berkata, kami senantiasa memerangi kaum (musyrik Mekah), kemudian Nabi saw, memanggil para

${ }^{16}$ Ibrahim Anis dkk, Al Mu'jam Al Washil Juz I (Mesir Dar Al Maarif 1392 H/1972 M), h 79

${ }^{17}$ Ibn Khald-n, Mukaddimah Ibn Khaldun tahkik Hamid Ahmad al-Tahir, Kairo: Dar al-Fajr li al-Turas, Cet 1 2004, h 265 
shahabat untuk berbaiat, maka baiat alRidwan itu dilaksanakan dibawah pohon: Para sahahabat berkata mereka berbaiat kepada Rasulullah saw, untuk mati. Jabir ibn Abdullah berkata: Rasul Allah tidak membaiat kami untuk mati, tetapi ia membaiat kami suapaya tidak lari. Rasul Allah membaiat, dan tidak ada seorang muslimyang tidak hadir, kecuali al-Jad bin Qays, saudara Bani Salimah. Jabir berkata: Demi Allah seakan-akan aku melihat al-jad melekat dan menempel diketiak untanya, berlindung dari pandangan orang. Kemudian berita datang kepada Rasul Allah saw, tentang Usman bin Affan (tidak terbunuh), maka berita itu batal. ${ }^{18}$

Lebih lanjut Ibn Hisyam dalam bukunya Sirah Ibn Hisyam dikemukakan riwayat dari al-Sya'abi, bahwa shahabat yang pertama mengangkat baiah, alRidwan kepada Rasulullah saw adalah Ab-Sinan al-Asadi. Riwayat dari lbn Umar bahwa Rasul Allah saw membaiat Usman dengan meletakkan tangannya atas tangan Usman.

Seseorang yang akan menjadi anggota tarekat terlebih dahulu melalui pembaiatan. Bagi Tarekat Khalawatiah Samman, upacara seperti itu disebut mattarima barakka (Bugis) annarima barakka (Makassar) yang arti harfiahnya

${ }^{18}$ Sirah lbn Hisyam. Juz 2, h 315 menerima berkah, inti barakka adalah anakmangaji (murid) menyatakan sumpah setiah kepada ajaran yang diberikan khalifahnya.

Menurut al-Samman dalam bukunya al-Nafahat al-llahiyyah seorang yang akan memasuki dunia tarekat, ia membutuhkan seorang syaikh yang akan membimbingnya, dan syaikh memberikan bimbingan kepada muridnya, bagaikan nabi memberikan bimbingan kepada ummatnya. Syaikh mendidik murid-muridnya bagaikan orang tua mendidik anaknya. Orang tua mengambil sumpah setia kepada anaknya untuk selalu menjauhi larangan dan mentaati seluruh perintah. ${ }^{19}$ Hal ini sesuai dengan sumpah setia para sahabat kepada nabi Muhammad saw, sebagaimana digambarkan dalam $\mathrm{Al}$ Qur'an surat al-Mumtahanat (60) ayat 12 yang berbunyi sebagai berikut:

"Hai Nabi, apabila datang kepadamu perempuan-perempuan yang beriman untuk Mengadakan janji setia, bahwa mereka tiada akan menyekutukan Allah, tidak akan mencuri, tidak akan berzina, tidak akan membunuh anak-anaknya, tidak akan berbuat Dusta yang mereka ada-adakan antara tangan dan kaki

${ }^{19}$ Muhammad bin Abd al-Karim alQuraysyiy al-Madaniy al-Sammaniy. Al-Nafahaat al-llaahiyyat fi Kaifiyyat Suluuk al-Thariqat alMuhammadiyyat (Mesir: al-Aadaab wa alMu'ayyad $1326 \mathrm{H}), \mathrm{h} 13$ 
mereka dan tidak akan mendurhakaimu dalam urusan yang baik, Maka terimalah janji setia mereka dan mohonkanlah ampunan kepada Allah untuk mereka. Sesungguhnya Allah Maha Pengampun lagi Maha Penyayang." QS. AlMumtahanaat (60):12

Al-Samman juga mengajarkan tatacara baiat, yaitu seorang murid yang akan menerima baiat, ia membentangkan tangannya di atas tangan seorang syaikh, baik perorangan, maupun kelompok, kemudian syaikh membaca ayat tentang baiat. QS al-Fath (48):10

"bahwasanya orang-orang yang berjanji setia kepada kamu Sesungguhnya mereka berjanji setia kepada Allah[1396]. tangan Allah di atas tangan mereka[1397], Maka Barangsiapa yang melanggar janjinya niscaya akibat ia melanggar janji itu akan menimpa dirinya sendiri dan Barangsiapa menepati janjinya kepada Allah Maka Allah akan memberinya pahala yang besar." QS. Al-Fath (48):IO

Orang yang sudah dibaiat, berarti ia sudah membuat perjanjian dengan orang yang membaiatnya, seperti seseorang yang membuat perjanjian dan bersumpah untuk menerima suatu pekerjaan, maka orang itu selalu rajin bekerja sesuai dengan sumpahnya itu. Begitu pula orang yag sudah dibaiat masuk suatu tarekat, ia selalau mengingat isi baiat itu, sehingga ia rajin beribadah kepada Allah, dan ia selalu menepati janjinya, karena menepati janji adalah salah satu perintah Tuhan, seperti yang ditegaskan dalam QS alMaidah (5): 1 berbunyi sebagai berikut:

"Hai orang-orang yang beriman, penuhilah aqad-aqad itu. Dihalalkan bagimu binatang ternak, kecuali yang akan dibacakan kepadamu. (yang demikian itu) dengan tidak menghalalkan berburu ketika kamu sedang mengerjakan haji. Sesungguhnya Allah menetapkan hukum-hukum menurut yang dikehendaki-Nya." QS AIMaidah (5):I

Ayat lain tentang perlunya menepati janji disebutkan dalam QS. AlNahl (16):91

“dan tepatilah Perjanjian dengan Allah apabila kamu berjanji dan janganlah kamu membatalkan sumpahsumpah(mu) itu, sesudah meneguhkannya, sedang kamu telah menjadikan Allah sebagai saksimu (terhadap sumpah-sumpahmu itu). Sesungguhnya Allah mengetahui apa yang kamu perbuat." QS. Al-Nahl (16):9l

Pada mulanya orang masuk Islam cukup mengucapkan dua kalimat syahadat, tetapi akibatnya banyak orang yang sudah masuk Islam, kemudian murtad lagi. Setelah isra dan mi'raj, baru diperinthakan nabi untuk melakukan baiat bagi orang yang berminat masuk lslam. Orang yang dibaiat berjanji akan melaksanakan perintah Tuhan, dan menjauhi laranganNya. Peristiwa baiat sudah 
terjadi di Aqabah, sebelum nabi hijrah, yaitu baiat sepuluh orang penduduk Madinah yang terdiri atas delapan orang suku Khazraj dan dua orang suku Aus. Persitiwa baiat kembali dilakukan nabi di tempat yang sama, yaitu baiat penduduk Madinah sebanyak 75 orang (baiat Ridwan, yaitu ketika nabi mendapat informasi bahwa Usman terbunuh) peristiwa itu mendapat ridlo dari Allah swt. Hal ini digambarkan dalam Al-Qur'an surat al-Fath (48) ayat 18 yang berbunyi:

"Sesungguhnya Allah telah ridha terhadap orang-orang mukmin ketika mereka berjanji setia kepadamu di bawah pohon, Maka Allah mengetahui apa yang ada dalam hati mereka lalu menurunkan ketenangan atas mereka dan memberi Balasan kepada mereka dengan kemenangan yang dekat (waktunya)." QS. Al-Fath (48):18

Ada tiga macam baiat yang dikenal di kalangan Tarekat Khalwatiah Samman, yaitu:

1. Baiat ketika masuk anggota dan biasanya pada usia baligh (15 tahun).

2. Baiat ketika mendapat arisinging (izin) mewakili khalifah ditingkat pusat, dan dia bertugas membaiat calon anggota baru, dan dia juga sudah dipanggil khalifah, tetapi tidak boleh mengangkat khalifah.
3. Baiat ketika diangkat menjadi khalifah yaitu pimpinan tarekat yang berkududukan di pusat, dan berhak mengangkat wakil (khalifah) di daerah-daerah. Orang yang dibaiat dalam bentuk ketiga ini biasanya yang khusus kepada orang yang mempunyai hubungan keluarga, yaitu antara ayah dan anak. Hal ini berlaku di pusat-pusat pengembangan Tarekat Khalwatiah Samman di Maros, yaitu Leppakomai dan Pattene, serta Parengki (Bantimurung)

Seseorang yang akan diangkat menjadi khalifah di daerah, baiasanya melalui satu jabatan yang dinamai pakkajara (pengajar), yaitu satu jabatan di bawah khalifah yang bertugas membantu khalifah di daerah kalau dia berhalangan. Pakkajara biasa menjadi imam, memimpin zikir, membimbing anggota dalam amalan ibadah seharihari, memimpin jamaah berziarah ke khalifah tingkat pusat, terutama dalam acara haul. Selain itu pakkajara dapat mengganti khalifah memimpin anggota jamaah menziarahi kuburan ulama Khalwatiah Samman terutama pada waktu acara haul, atau sesudah lebaran. Seorang pakkajara dengan pengalamannya dan sering bertemu khalifah di tingkat pusat, maka dia juga dapat diangkat menjadi khalifah, kalau 
khalifah di daerahnya sudah tua atau sudah meninggal. Namun tidak menjadi keharusan bahwa seorang khalifah di daerah harus melalui jenjang pakkajara terlebih dahulu. Nampaknya setiap khalifah tingkat pusat ada seorang khalifah yang dianggap senior yang bertugas memantau orang-orang yang pantas menjadi khalifah dan aerahdaerah yang membutuhkan khalifah. Seseorang yang akan diangkat menjadi khalifah biasanya mendapat rekomendasi dari khalifah yang dianggap senior. Pembaiatan khalifah yang bertugas di daerah-daerah biasanya dilakukan sesudah haul yang dirangkaikan maulid di pattene. Hal ini dilakukan kalau orang yang akan dibaiat itu berasal dari daerah yang jauh, seperti pembaiatan kepada tiga khalifah dari Riau, Sumatra oleh Andi Hamzah Puang Nippi pada tahun 1995 di Pattene, Maros seorang yang mendapat arisingeng (izin), diberi secarik kertas sebagai surat keterangan yang terdapat silsilah tarekat dengan nama khalifah yang member izin biasanya berada pada urutan paling di bawah atau paling di atas kemudian diberi foto dan identitas khalifah yang dibaiat, selanjutnya surat keterangan itu ditandatangani oleh khalifah tingkat pusat yang member izin.
Silsilah sangat penting bagi pengikut suatu tarekat, karena mereka mengaku bahwa dasar-dasar pemikiran dan pengalaman tarekat bersumber dari nabi. Nama-nama para guru yang mengajarkan tarekat secara berurutan harus sampai kepada nabi. Setiap khalifah sangat hati-hati memelihara silsilahnya, karena silsilah itu sebagai kartu identitas dan legitimasi yang menunjukan hubungan dengan guru tarekat lainnya. Silsilah khalifah Tarekat Khalwatiah Samman, Abdullah berada pada urutan ke-45, kemudian dia diganti oleh tiga anaknya yaitu Muhammad Shaleh, Muhammad Amin, dan Ibrahim, dan ketiganya itu barada pada urutan ke-46. Kemudian ketiga khalifah itu digantikan oleh anaknya masing-masing. Mereka itu menempati urutan ke-47, di bawah nama ayahnya. Muhammad Shaleh mengangkat dua anaknya, yaitu Haji Andi Amiruddin (w 1979) Haji Andi Hamzah Puang Nippi. Muhammad Amin membaiat anaknya, Abd Rauf Puang Lallo (w 1978) dan dia juga membaiat salah seorang muridnya (menantu Abd Rauf Puang lallo) Andi Abdullah Puang Ngatta (tinggal di Pekkasalo Maros), sekalipun dia bukan anaknya, mungkin dia melihat bahwa Andi Abdullah adalah cucu Muhammad Fudail, pendiri Tarekat Khalwatiah Samman di Sulawesi Selatan. Ibrahim 
Puang Solong digantikan oleh anaknya. Haji Andi Abdullah Puang Rala. Hanya Andi Muhammad Ali Puang Ngatta di Leppakomai menempati urutan ke-48 menggantikan ayahnya Abd Rauf Puang lallo. ${ }^{20}$

Tatacara pelaksanaan baiat yang dilaksanakan Tarekat Khalwatiah Samman sudah mengalami modifikasi, dan tidak persis sama apa yang diajarkan al-Samman dalam bukunya alNafahat al-llahiyyah. Seorang calon anak mangngaji (murid) yang akan dibaiat, dia harus bersih dari hadas besar dan hadas kecil. Bagi orang yang hadas besar dia lebih dahulu mandi, dan yang berhadas kecil dia harus berwudhu. Selain itu calon murid terlebih dahulu membersihkan jiwanya dengan taubat. Upacara baiat biasanya dilakukan kalau calon anggota sudah sampai 40 orang, dan dilakukan di masjid bagi daerah yang mempunyai masjid tersendiri, atau dirumah khalifah, dan diadakan pada

${ }^{20}$ Keabsahan suatu silsilah kalau silsilah itu bersambung sampai kepada nabi SAW tetapi ulama sufi menganggap bahwa sekalipun nama yang berurutan tidak mungkin bertemu karena yang pertama wafat sebelum yang kedua lahir atau keduanya berjauhan, tetapi dalam dunia tarekat dikenal baiat barzakhi uwarisi. Dinamai barzakhi karena pembaiatan berasal dari alam barzakh, yaitu alam antara sebelum ruh orang yang meninggal dibangkitkan, sedangkan istilah uwaisi yaitu berasal dari nama Uwais Al Qarni seorang Yaman sezaman dengan nabi yang tidak pernah bertemu dengan nabi, tetapi dipercayai telah dilslamkan oleh ruh Nabi sebelum wafat. Lihat Martin Van Bruinessen, Tarekat Naqsabandiyah di Indonesia (Bandung Mizan, cet Il, 1994), h 49 malam hari. Sebelum baiat dimulai, khalifah bertanya kepada calon murid atas kesediaannya untuk setia menjalankan aturan-aturan tarekat yang diajarkan, dan dengan menganggukkan kepala saja, suatu pernyataan bahwa sang murid sudah berjanji untuk taat kepada khalifah. Calon murid duduk membuat lingkaran dengan memegang tasbih yang terbuat dari manik-manik besar, sebagai symbol bahwa antara murid dengan khalifahnya, dan antara sesama murid, sejak peristiwa itu mulai terjalin ikatan. Selain itu, tangan murid yang memegang tasbih menghadap ke atas melambangkan harapan murid terhadap ilmu dan bimbingan khalifah, sedangkan tangan khalifah menghadap ke bawah melambangkan khalifah akan memberikan ilmu, nasehat-nasehat, dan bimbingan. Mereka juga memakai pakaian putih-putih dan khalifah lengkap dengan peci putih, sebagai pertanda kesucian dan kebersihan jiwa yang merupakan salah satu persyaratan seorang pengikut tarekat untuk dekat dengan Tuhan yang merupakan tujuan tarekat. Sesudah pembaiatan disuguhkan makanan yang disediakan oleh anggota jamaah Tarekat Khalwatiyah Samman

Sekarang upacara baiat tidak terlalu ketat lagi, seperti yang telah digambarkan. Kalau pembaiatan secara 
perorangan maka calon anggota biasanya memegang tasbih kecil, atau hanya berjabat tangan saja, dan pakaian tidak musti pakaian putih. Begitupula kalau satu kelompok yang mau dibaiat, tetapi tidak diketemukan lagi tasbih yang besar, biasa juga dipergunakan tali plastik (dahulu dipergunakan tali sabut) sebagai symbol tali ikatan mereka. Masalah waktu yang dahulu biasa pada malam hari, sekarang tidak mutlak lagi, kapan saja waktu disepakati.

\section{Dzikir}

Zikir berasal dari bahasa Arab, zakara, yazkuru, zikr artinya

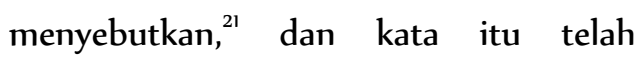
menjadi perbendaharaan kata bahasa Indonesia yang berarti puji-pujian kepada Allah yang diucapkan berulangulang. $^{22}$ Yang dimaksudkan disini adalah lafal-lafal yang diajarkan oleh khalifah, dan diucapkan secara teratur untuk mendekatkan diri kepada Allah SWT, sehingga zikir juga biasa disebut ratib, kata ratib bentuk ism al-fail dalam bahasa arab, rataba, yartubu, rutub artinya teratur. ${ }^{23}$ Ratib dalam bahasa Indonesia berarti puji-pujian atau do'a

${ }^{21}$ lbrahim Anis dkk, Al Mu'jam Al Washil Juz 1 (Mesir Dar Al Maarif 1392 H/1972 M), h 31

${ }^{22}$ Departemen Pendidikan dan Kebudayaan, Kamus Besar Bahasa Indonesia (Jakarta Balai Pustaka Cet Ill 1990), h 18

${ }^{23}$ Pengikut Khalwatiah Samman di Sulawesi Selatan biasa dipanggil paddate (orang yang ratib) tetapi ratib samman yang dikenal di Jawa dan Sumatra tidak dikenal di Sulawesi selatan kepada Tuhan yang diucapkan berulangulang seperti laailahaillallah. ${ }^{24}$

Selain zikir Khalwat (menyendiri) dimuat juga dalam kitab Al-Samman AlNafahat al-llahiyyah, Al-Samman mebagi khalwat dalam tiga tingkat, yaitu khalwat salik, arif dan muhaqqiq.

1. Khalwat salik adalah khalwat bagi anggota yang baru masuk tarekat.

2. Khalwat arif yang dinamai juga khalwat mutlak, yaitu khalwat dalam hati saja.

3. Khalwat muhaqqiq yaitu khalwat billah (dengan pertolongan Allah, dan khalwat ini hanya satu orang dalam satu masa, dan diberikan khusus kepada qutub al-gaws yaitu orang yang sudah sampai puncak tertinggi dalam tasawuf. ${ }^{25}$

Ajaran khalwat tidak diketemukan dalam karya tulis Khalifah Tarekat Khalwatiyah Samman, namun mereka juga mengenal khalwat yang dinamai khalwat al-'arif yaitu khalwat dalam hati saja, yakni berkhalwat meskipun dalam keramaian.

Muraqabah merupakan bagian dari ajaran al-Samman, yaitu ajaran yang

\footnotetext{
${ }^{24}$ Departemen Pendidikan dan Kebudayaan, Kamus Besar Bahasa Indonesia (Jakarta Balai Pustaka Cet 111 1990), h 751

${ }^{25}$ Muhammad bin Abd al-Karim al-Quraysyiy alMadaniy al-Sammaniy. Al-Nafahaat al-llaahiyyat fi Kaifiyyat Suluuk al-Thariqat alMuhammadiyyat (Mesir: al-Aadaab wa alMu'ayyad 1326 H), h 33-34
} 
mengintai dan mengintip Tuhan untuk menempatkan diri dekat kepada-Nya. Ajaran al-Samman tentang muraqabah dibawah oleh salah seorang muridnya, Muhammad bin Syais Sumbul al-Makkiy ke Buton (Sulawesi Tenggara) dan dia mengajarkan kepada Adrus, Sultan Buton (1824-1851). Menurut Adrus, muraqabahdatang setelah muhasabah. Muhasabah adalah senantiasa mengoreksidirinya dari segala masa lalunya dan memperbaiki dirinya dimana dia berada dan senantiasa berada pada jalan yang benar dan mengadakan kontak kepada Tuhan, menjaga untuk selalu bersama dengan Tuhan. Muraqabah terbukanya tabir sehingga Tuhan dapat dilihat dengan mata hati. ${ }^{26}$ Seperti juga khalwat ajaran muraqabah tidak diketemukan dalam tulisan-tulisan khalifah Tarekat Khalwatiyah Samman. Ajaran ini kurang dikenal di kalangan pengikut-pengikut Tarekat Khalwatiyah Samman diSulawesi Selatan.

Al-Samman dalam bukunya $A /$ Nafahat al-llahiyyah dan menyebutkan beberapa ayat dan hadis tentang keutamaan zikir, seperti al-Ahzab (33):41

${ }^{26}$ Abd. Rahman Yunus, Posisi Umat Islam Kekuatan di Kesultanan Buton pada abad ke-19. Th 1998 h 92
"Hai orang-orang yang beriman, berzdikirlah (dengan menyebut nama) Allah, zikir yang sebanyak-banyaknya." (QS. Al Ahzab (33):4I)

Ayat lain tentang zikir dalam Qur'an Surat Al Baqarah (2): 152

"Karena itu, ingatlah kamu kepada-Ku niscaya Aku ingat (pula) kepadamu, dan bersyukurlah kepada-Ku, dan janganlah kamu mengingkari (nikmat)-Ku. (QS Al Baqarah (2):152

Menurut Al-Samman ayat yang mengatakan fa uzkuruniy azkurukum artinya ingatlah Aku dengan mengabdi kepada-Ku dan aku mengingatmu dengan member nikmat kepadamu. Zikir dapat menentramkan hati, sesuai dengan QS al-ra'd (13):28

"(yaitu) orang-orang yang beriman dan hati mereka manjadi tenteram dengan mengingat Allah. Ingatlah, hanya dengan mengingati Allah-lah hati menjadi tenteram." QS al-Ra'd (13) : 28

Selain ayat al-qur'an, disebut juga beberapa hadits tentang keutamaan zikir, salah satu hadits yang dikemukakan adalah

"Barang siapa mencintai sesuatu dia banyak menyebutnya"

Al-Samman menjelaskan hadits tersebut bahwa orang mencintai sesuatu, dia tidak akan melupakan yang dicintainya baik dia jauh maupun 
dekat. ${ }^{27}$ Selain ayat Al-Qur'an tentang zikir yang disebut oleh al-Samman juga beberapa tokoh Tarekat Khalwatiah Samman mengemukakan ayat tentang keutamaan zikir dalam bukunya, seperti Abd Razak dan Muhammad Syattar, mengemukakan Al-Qur'an Surat AlNisa (4):103

"Maka apabila kamu Telah menyelesaikan shalat(mu), ingatlah Allah di waktu berdiri, di waktu duduk dan di waktu berbaring. Kemudian apabila kamu Telah merasa aman, Maka Dirikanlah shalat itu (sebagaimana biasa). Sesungguhnya shalat itu adalah fardhu yang ditentukan waktunya atas orang-orang yang beriman". (QS Al-Nisa (4):103).

$$
\text { Ayat-ayat yang telah }
$$

dikemukakan memberikan keterangan bahwa Allah menganjurkan hamba-Nya berzikir, mengingat dan menyebut nama-Nya, tetapi tidak dijelaskan lafal zikir yang harus diucapkan. Untuk zikir nabi saw telah menjelaskan lafal yang utama dipergunakan seorang hamba untuk mengingat Allah, dan salah satu hadits yang member petunjuk bahwa lafal zikir naif isbat yaitu la ilaha illa Allah adalah lafal zikir yang paling afdal dari pada lafal zikir yang lainnya.

"Seutama-utama zikir adalah laa ilaha illa Allah"

${ }^{27}$ Muhammad bin Abd Al-Karim Al-Kasysyy, AlMadani Al-Sammani, h 14
Banyak hadits yang menjelaskan bahwa zikir lafal nafi' isbat banyak keutamaannya. Di dalam keutamaan zikir tersebut dapat memperbaharui iman seseorang. Hal ini seuai dengan sabda Nabi Muhammad saw yang berbunyi

“Perbaharuilah imanmu (sahabat) bertanya bagaimana memperbaharui iman ya Rasulallah, Rasul menjawab perbanyaklah membaca laa ilaha illa Allah"

Keutamaan lain lafal zikir naif isbat ialah orang yang menjadikan lafal itu sebagai akhir ucapannya, dia dijamin akan masuk syurga, sesuai dengan sabda Nabi Muhammad saw yang berbunyi

“Tidak ada seorang abdi yang mengucapkan laailaha illa Allah kemudian dia mati kecuali dia masuk syurga"

Selain ayat Al-Qur'an dan Hadits, dapat diketemukan juga ucapan sufi tentang keutamaan zikir naif isbat yang dikutip oleh Abdullah sebagai berikut

"Barang siapa membaca laa ilaha illa Allah dengan ikhlas, dia akan diampuni 4000 dosa besarnya"

Zikir yang merupakan ajaran terpenting dalam tarekat dapat dibagi kedalam zikir sir (dalam hati) dan zikir jahr (keras), dan keduanya dibenarkan, karena sesuai dengan QS Al-Mulk (67):13 
"dan rahasiakanlah perkataanmu atau

lahirkanlah; Sesungguhnya Dia Maha mengetahui segala isi hati." QS. Al-Mulk

Menurut Ibrahim, zikir sir lebih afdal daripada zikirjahr kalau orang yang berzikir itu khawatir muncul perasaan ria atau dapat mengganggu orang lain, seperti orang tidur akan tetapi kalau hal tersebut dapat dihindari, maka zikir dengan jahr lebih afdal, karena manfaatnya sangat banyak, antara lain dapat menghilangkan kemalasan dan menyadarkan hati. $^{28}$ Menurut Muhammad Syattar, zikir jahr sudah dikenal pada zaman Rasulullah saw. Hal ini dapat diketemukan riwayat ibn Abbas yang diriwayatkan Bukhari

"Hadits diriwayatkan Ibn Abbas yang diridlai keduanya berkata: zikir dengan suara keras, telah dilaksanakan pada masa Nabi saw dan dilakukan setelah jamaah keluar dari sholat fardu. Ibn Abbas berkata: Hal itu aku mengetahui dan aku mendengarkannya."

Dua bentuk zikir tersebut, dikenal juga dalam Tarekat Khalwatiah Samman. Pertama, zikir sir yakni zikir dalam hati dinamai sikkiri seppulo (zikir sepuluh) yaitu zikir yang hanya mengucapkan lafal zikir sebanyak sepuluh kali. Zikir sepuluh dilakukan kalau kesempatan tidak mengizinkan,

\footnotetext{
${ }^{28} \mathrm{Haji}$ lbrahim, Tasawuf tulisan tangan pemberian judul disesuaikan dengan isi naska, berbahasa Bugis dan Arab, aksara Lontara dan arab milik Andi Manggalatung Welado, Bone.
}

seperti dalam keadaan musafir, dapat mengganggu orang lain (orang sakit, orang tidur) atau dalam keadaan kesehatan terganggu. Kedua zikir jahr, yakni zikir dengan suara keras dan dinamai sikkiri tellu ratu yaitu zikir yang terdiri dari tiga ratus kali ucapan lafal zikir atau lebih.

Menurut Abdullah, ada ulama tarekat yang memilih zikir sir (dalam hati) dan ada juga yang memilih zikir jahr (keras). Namun disunnahkan zikir jahr, karena zikir jahr manfaatnya antara lain, menampakkan syiar Islam, memberi berkah kepada orang yang mendengarkannya, menghapus dosa dan menumbuhkan iman. $^{29}$ Dalam kitab lgasat al-Lahfan digambarkan orang yang zikir dengan suara keras bagaikan tukang besi yang memukulkan palunya untuk menghilangkan karatan yang melengket pada besi, begitupula orang yang berzikir jahr dapat menghilangkan dosa yang melekat dalam hatinya. Orang yang berzikir dalam satu lingkaran dengan menggerakkan tubuh, syethan tidak dapat masuk untuk menggoda. Selain itu zikir dengan menggerakkan anggota tubuh dapat menghancurkan kotoran berupa dosa karena lupa atau makan sesuatu yang diharamkan.

\footnotetext{
${ }^{29}$ Abdullah bin Abd Razak, Tasawuf, h 32
} 
Dosa manusia terdiri atas dosa lahir dan dosa batin. Dosa lahir yaitu dosa yang disebabkan oleh lidah atau anggota tubuh lainnya, dan dapat dihapus dengan sholat lima waktu dan taubat disertai dengan keyakinan tidak akan melakukan dosa itu. Namun dosa batin hanya dapat dihapus dengan zikir. Dosa batin itu terdapat dalam sanubari yang letaknya pada susu sebelah kiri. Hati sanubari itu selalu dibersihkan dengan zikir, karena ditempati dengan sepuluh penyakit batin, yaitu pettanngati (hati yang gelap), ja ateka (itikad salah), lampe nawa-nawa (panjang angan-angan), takkabboro (takabur), puji ale (ria), pengempurung (cemburu), temmapasikuwa (tidak merasa puas), tanre ati (tinggi hati), ja kapang (prasangka tidak baik). Oleh karena itu kalau hati seseorang baik, maka baiklah orang itu, begitu pula sebaliknya, kalau hatinya jelek, maka dia juga jelek. Sesuai dengan sabda Nabi saw

"sesungguhnya pada diri seseorang terdapat segumpal daging, dan kalau segumpal daging itu dan apabila segumpal daging itu baik maka seluruh anggota tubuhnya baik pula, tetapi kalau segumpal daging itu jelek, maka seluruh anggota tubuhnya juga jelek, yaitu hati"

Menurut Tarekat Khalwatiah Samman, zikir itu dapat dibagi atas tiga bagian, yaitu Khalwatiah, qadiriyah, afnaiyyah. Khalwatiah mempunyai empat arti yaitu. 1). Tidak ada yang disembah selain Allah (la ma'bud illa Allah). 2) Tidak ada yang dimaksud kecuali Allah (la maqsud illa Allah), 3) tidak ada yang dicari kecuali Allah (la mathlub illa Allah) 4) tidak ada yang wujud kecuali Allah (la mawjud illa Allah). Qaidiriyyah mempunyai tiga arti yakni I) Tidak ada yang disembah selain Allah (la ma'bud illa Allah). 2) Tidak ada yang dimaksud kecuali Allah (la maqsud illa Allah), 3) tidak ada yang dicari kecuali Allah (la mathlub illa Allah). Afnawiyah hanya mempunyai satu arti yaitu tidak ada yang wujud kecuali Allah (la mawjud illa Allah). ${ }^{30}$

Tata cara pelaksanaan zikir jahar Tarekat Khalwatiah Samman sebelum dimulai zikir, yakni duduk sebagaimana duduk tahiyyat awal dalam sholat, menghadap kiblat kemudian membaca surat Al-Fatihah sebanyak tiga kali, dan diniatkan pahalanya sampai kepada seluruh guru yang ada dalam silsilah Tarekat Khalwatyah Samman sampai kepada Nabi, shahabat dan keuarganya, seluruh orang mukmin dan kedua orang tua kemudian dibaca shalawat kepada Nabi

${ }^{30}$ Muhammad Shaleh, Zikir Khalwatiah samman, judul diberikan sesuai dengan isi naskah. Bahasa Bugis dan Arab 


\section{Sholat Dhuhur setelah Jum'at}

Sholat dhuhur setelah jum'at hemat penulis tidaklah termasuk ajaran inti dari Tarekat Khalwatiah Samman, seperti ajaran yang telah penulis jelaskan di atas. Namun penulis merasa perlu untuk mengangkat materi ini, sebab kebiasaan dalam jamaah Tarekat Khalwatiah Samman adalah melakukan sholat dhuhur setelah melaksanakan sholat jum'at. Hal ini dimaksudkan untuk memberikan pemahaman tentang alasan melaksanakan sholat dhuhur setelah jum'at bagi tarekat Khalwatiayah Samman.

Bagi Tarekat Khalwatiyah Samman sholat dhuhur setelah sholat jum'at merupakan kebiasaan yang dilakukan dengan landasan Al-Qur'an surat al-Jumu'ah ayat 9 yang berbunyi

"Hai orang-orang beriman, apabila diseru untuk menunaikan shalat Jum'at, Maka bersegeralah kamu kepada mengingat Allah dan tinggalkanlah jual beli[1475]. yang demikian itu lebih baik bagimu jika kamu Mengetahui" QS AlJumu'ah (62):9.

Para ahli tafsir sepakat bahwa surat al-jumu'ah ini tergolong sebagai surat yang diturunkan di Madinah setelah Rasulullah saw, hijrah ke Madinah. Hal ini menunjukkan bahwa perintah shalat jum'at datang setelah Rasulullah hijrah ke Madinah. Perintah itu tidak bersamaan datangnya perintah shalat wajib dilaksanakan pada lima waktu yang telah ditentukan; lsya, shubuh, zhuhur, ashar dan maghrib. Perintah shalat-shalat itu diturunkan sebelum Rasulullah saw hijrah, ke Madinah yakni pada waktu Rasulullah saw melakukan isra' dan mi'raj.

Menurut Andi Najamuddin Hamzah, S.Ag, M.Ag dalam bukunya sejarah Tarekat Khalwatiah Samman, bahwa penyebab melaksanakan sholat dhuhur setelah sholat jum'at, dikarenakan alif laim (ال) yang terdapat pada kata (الصلاة) pada ayat 9 di atas itu adalah sholat jum'at bila ditinjau dari segi sebab turunnya wahyu, sehingga ulama lughat (bahasa) mengatakan bahwa alif lam itu adalah marifat artinya sudah tertentu yang dimaksud. Sementara kata sholat pada ayat 10 yang berbunyi

"Apabila Telah ditunaikan shalat, Maka bertebaranlah kamu di muka bumi; dan carilah karunia Allah dan ingatlah Allah banyak-banyak supaya kamu beruntung." (QS. Al-Jumuah (62):IO)

Kata (الصلاة) pada ayat 10 adalah alif lam (ال) jinsiyah artinya menunjukan 
semua jenis sholat. Jadi kalau sudah melaksanakan sholat (baik sholat fardu maupun sholat sunah) pergilah mencari rizki yang halal. Sedangkan kalimat

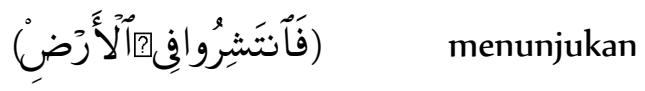
perintah mubah (dilaksanakan boleh tidak dilaksanakan juga boleh) dan bukan wajib, serta tidak menunjukkan harus meninggalkan beberapa rangkaian ibadah setelah melaksnakan sholat jum'at, ${ }^{31}$ perintah sholat dhuhur itu datang lebih awal dibanding sholat jum'at, lebih kurang dua tahun antaranya dan tidak ditemukan persoalan nasikh dan mansukh dari kedua perintah tersebut. Artinya perintah kedua (sholat jum'at) tidak membatalkan perintah pertama (sholat dhuhur). Yang menunjukkan nabi Muhammad saw menerima perintah sholat lima waktu yaitu pada surat $\mathrm{Al}-$ Isra ayat ${ }^{32}$

"Maha Suci Allah, yang Telah memperjalankan hamba-Nya pada suatu malam dari Al Masjidil Haram ke Al Masjidil Aqsha yang Telah kami berkahi sekelilingnya agar kami perlihatkan kepadanya sebagian dari tanda-tanda

${ }^{31}$ Andi Najamuddin, S.Ag, M.Ag, Sejarah Tarekat Khalwatiah Samman Ajaran dan Stretegi Dakwah Para Khalifahnya, (Jakarta PT. Pustaka Indonesia Press (PIP) cet 11 2007), h 99

${ }^{32}$ Andi Najamuddin, S.Ag, M.Ag, Sejarah Tarekat Khalwatiah Samman Ajaran dan Stretegi Dakwah Para Khalifahnya, (Jakarta PT. Pustaka Indonesia Press (PIP) cet 11 2007), h 100 (kebesaran) kami. Sesungguhnya dia adalah Maha mendengar lagi Maha Mengetahui." (QS. Al-Isra (17):I)

Menurut Andi Hidayat, Khalifah Tarekat Khalwatiah Samman Wilayah Turikale Kabupaten Maros-Sulawesi Selatan, bahwa kalau kita menelusuri ayat Al-Qur'an yang mewajibkan shalat jum'at dan menyimak secara seksama peristiwa isra' mi'raj tersebut, maka dapat diambil kesimpulan bahwa ada dua macam perintah yang harus dikerjakan, yaitu shalat zhuhur, kemudian perintah shalat jum'at. jika kita mengkaji ayat tentang perintah shalat jum'at yang diturunkan kemudian, maka kita tidak menemukan adanya satupun lafazh yang menggugurkan perintah pertama (shalat lima waktu), khusunya shalat zhuhur, meskipun pelaksanaannya disyariatkan pada hari jum'at di waktu zhuhur. Artinya menempatkan shalat diwaktu shalat yang lain bukan berarti menghilangkan atau menggugurkan shalat tersebut. Demikian pula di dalam hadits Rasulullah kita tidak menemukan adanya dalil secara tegas yang menyatakan gugurnya kewajiban shalat zhuhur pada hari jum'at. Bahkan secara gamlang Abd. Al-Rahman al-jaziry di dalam kitab al-fiqhi 'ala al-Mazahib alArba'ah menyatakan 
Artinya: "Shalat jum'at merupakan fardu 'ain bagi setiap orang mukallaf yang mampu memenuhi syarat-syaratnya. la (shalat jum'at) bukan pengganti dari shalat zhuhur".

Syaikh Muhammad Amin bin Abdullah bin Abd Razak, mengatakan saya pernah ke Mesir, saya sengaja mengambil shaf yang paling belakang untuk melihat apakah di Mesir, ada shalat zhuhur setelah jum'at sama seperti yang diajarkan oleh bapak saya Syekh Abdullah bin Abd Razak, tentang shalat zhuhur setelah shalat jum'at. Ternyata setelah selesai shalat jum'at tak satupun orang yang keluar dari masjid semuanya melaksanakan shalat zhuhur di Mesir pada saat itu. Saya (Syaikh Muhammad Amin) yakin bahwa apa yang diajarkan orang tua saya (Syeihk Abdullah bin Abd Razak) adalah benar.

\section{KESIMPULAN}

Tarekat Khalwatiah Samman didirikan oleh Muhammad Al Samman di Mdinah dan diperkenalkan di Indonesia oleh muridnya, Abdul Samad Al Palembany lewat tulisannya dalam bahasa Melayu, dan salah seorang murid Al Samman, Muhammad bin Syais Al Makki memperkenalkan ajaran $\mathrm{Al}$ Samman kepada Aidrus, Sultn Buton.

$$
\text { Ajaran Tarekat Khalwatiah }
$$

Samman bersumber dari kitab Abd al
Karim Al Samman al Nafahat al llahiyyat fi Kaifiyat Suluk al Tarikat al Muhammadiyah

Ajaran Tarekat Khalwatiah samman yaitu syariah, hakikat baiat, zikir dan faham wujud, sholat zhuhur di hari Jumat dan Mahabbah semuanya didikung dengan dalil al Quran, hadits dan ungkapan ulama tasawwuf atau tarekat.

Syariat dalam pemahaman Tarikat Khalwatiah Samman tidak terbatas masalah fiqh atau hokum, tetapi mencakup pula aqidah dan akhlaq. Syariat bukan sekedar kumpulan undang-undang atau peraturan yang mengatur tindakan lahir. Akan tetapi syariat juga menjelaskan tentang keimanan, tauhid, cinta, syukur, sabar, ibadah, zikir, jihad, taqwa dan ihsan.

$$
\text { Baiat adalah suatu upacara }
$$

untuk beralih masuk kelompok tarekat yang merupakan symbol ikatanantara murid dan dengan khalifah, menurut al Samman dalam kitabnya al Nafahat al llahiyyat, seorang yang akan memasuki dunia tarekat ia membutuhkan seorang syekh yang akan membimbingnya dan syekh memberikan bimbingan kepada muridnya, bagaikan nabi memberikan bimbingan kepada ummatnya. Syekh mendidik murid-muridnya bagaikan orang tua mendidik anaknya. 
Suatu Tarekat dikatakan benar apabila silsilah ajaran tarekat tersebut sampai kepada Muhammad saw. Tarekat Khalwatiah Samman, merupakan salah satu tarekat yang muqtabarah, karena silsilah sampai kepada rasulullah Muhammad SAW.

\section{DAFTAR PUSTAKA}

Abdullah bin Abd. Razak (1954). Pelaksanaan Ibadah Khalwatiah. Lontara ini disalin oleh Syamsuddin Riau.

Abdurrahman, Haji Muhammad Zainuddin. Lontara Khalwatiah Samman. Bahasa Bugis Arab milik Daeng Sikki

Ali Duraib, Sa'ad Ibn Sa'ad (2001). Dalam Hamka Haq: Wacana dan Penerapannya. Ujung Pandang. Yayasan al-Ahkam

Al-Qur'an al-Karim dan Terjemahannya, Departemen Agama, tahun 2007

Andi Hidayat (Puang Daya) Imam Masjid Khalwatiyah Turikale Maros Sulawesi Selatan

Anis, lbrahim dkk. Al Mu'jam al Wasit Juz Il Mesir, Dar al Ma'arif 1393
Ansari, Muhammad Abdul Haq. Sufisme dan Shariah: a story of Shykh Ahmad Sirhindi's Efforthykh Ahmad Sirhindi's Effort to Reform Sufism. Diterjemahkan oleh Ahmad Nasir Budiman dengan judul Antara Sufisme dan Shariah. Jakarta Rajawali Press

Departemen Pendidikan Nasional (1986). Lontara Bilang Raja Gowa dan Tallo Transliterasi dan Terjemahan dan Pengkajian Kebudayaan Sulawesi Selatan La Galigo

Gazur, Shayk Ibrahim. Al Hallaj Ana Al Haq. Diterjemahkan oleh $\mathrm{Hr}$. Bandahoro dan Joebaar Ajoeh dengan judul Mengungkap Misteri Sufi Besar Mansur al Hajjaj Ana al Haq. Cet 11; Jakarta Rajawali Press, 1986

Muhammad S. (1954) Lontara ini disalin oleh Syamsuddin Riau.

Muhammad Sholeh. Zikir Khalwatiah Samman holeh. Zikir Khalwatiah Samman Naskah Bugis Arab

Munawir, Ahmad Warson Al Munawwir Kamus Bahasa Arab Indonesia. Jakarta Balai Pustaka Cet III 1990 